\title{
Annual follow-up of gross diffusive carbon dioxide and methane emissions from a boreal reservoir and two nearby lakes in Québec, Canada
}

\author{
M. Demarty ${ }^{1}$, J. Bastien ${ }^{1}$, and A. Tremblay ${ }^{2}$ \\ ${ }^{1}$ Environnement Illimité inc., 1453, rue Saint-Timothée, Montréal, Québec, Canada \\ ${ }^{2}$ Hydro-Québec, 75, boul. René-Lévesque Ouest, Montréal, Québec, Canada \\ Received: 14 May 2010 - Published in Biogeosciences Discuss.: 13 July 2010 \\ Revised: 15 November 2010 - Accepted: 13 December 2010 - Published: 6 January 2011
}

\begin{abstract}
Surface water $p \mathrm{CO}_{2}$ and $p \mathrm{CH}_{4}$ measurements were taken in the boreal zone of Québec, Canada, from summer 2006 to summer 2008 in Eastmain 1 reservoir and two nearby lakes. The goal of this follow-up was to evaluate annual greenhouse gas (GHG) emissions, including spring emissions (N.B. gross emissions for reservoir), through flux calculations using the thin boundary layer model. Our measurements underscored the winter $\mathrm{CO}_{2}$ accumulation due to ice cover and the importance of a reliable estimate of spring diffusive emissions as the ice breaks up. We clearly demonstrated that in our systems, diffusive $\mathrm{CH}_{4}$ flux (in terms of $\mathrm{CO}_{2}$ equivalent) were of minor importance in the GHG emissions (without $\mathrm{CH}_{4}$ accumulation under ice), with diffusive $\mathrm{CO}_{2}$ flux generally accounting for more than $95 \%$ of the annual diffusive flux. We also noted the extent of spring diffusive $\mathrm{CO}_{2}$ emissions (23\% to $52 \%$ ) in the annual carbon budget.
\end{abstract}

\section{Introduction}

The involvement of freshwater ecosystems in the global carbon budget has long been neglected because of their limited surface coverage on a worldwide scale, compared with forest or oceans. However, in a recent review, Cole et al. (2007) demonstrated that lakes, reservoirs and rivers do not behave as mere pipelines transporting organic matter from terrestrial systems to oceans. Actually, half of the carbon annually entering freshwater ecosystems is processed therein (i.e., biomass production, emissions, storage) and will never reach the ocean.

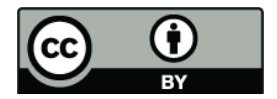

Correspondence to: M. Demarty (maud.demarty@envill.com)
It has also been demonstrated that the loading of terrestrial dissolved organic carbon can contribute significantly to the energy pathways of lake ecosystems (Tranvik, 1992; Pace et al., 2004; Carpenter et al., 2005), sometimes leading to respiration rates exceeding primary production rates (Del Giorgio et al., 1997). This state, also called ecosystem net heterotrophy, is believed to be largely responsible for the $\mathrm{CO}_{2}$ supersaturation observed in most of the world's lakes (Cole et al., 1994; Del Giorgio et al., 1999; Duarte and Prairie, 2005). Lakes thus clearly appear to be sources of carbon emissions to the atmosphere.

In the nineties, direct diffusive flux measurements from natural water bodies and diffusive flux calculations from partial pressure measurements were carried out in the northern hemisphere (Kling et al., 1992; MacIntyre et al., 1995) and in tropical zones (Richey et al., 1988; Keller and Stallard, 1994). Following the statements of Rudd et al. (1993) and St. Louis et al. (2000) about the potential of reservoirs to be net greenhouse gas (GHG) emitters, the techniques developed for GHG measurements in natural systems have been applied to reservoirs. A comprehensive understanding of the processes involved in the global carbon cycle in reservoirs is becoming more and more crucial to ensure accurate comparisons of energy production methods and determination of national GHG inventories (IPCC, 2006; Houghton et al., 2001).

Reservoirs can emit GHGs by three major pathways, the first two of which are also observed in natural water bodies: (1) diffusion at the reservoir surface (Huttunen et al., 2003; Rosa et al., 2004), (2) bubbles produced at the sedimentwater interface that migrate through the water column and into the atmosphere (Huttunen et al., 2003; Abril et al., 2005), and (3) downstream emissions, which include degassing (diffusive emissions in the turbulent waters downstream of reservoirs, called degassing emissions to differentiate them from the diffusive emissions at the reservoir's

Published by Copernicus Publications on behalf of the European Geosciences Union. 
Table 1. Description of study site.

\begin{tabular}{lllccccc}
\hline Study site & Latitude & Longitude & $\begin{array}{c}\text { Surface } \\
\left(\mathrm{km}^{2}\right)\end{array}$ & $\begin{array}{c}\text { Residence } \\
\text { time }(\text { month) }\end{array}$ & $\begin{array}{c}\text { Mean } \\
\text { depth }(\mathrm{m})\end{array}$ & $\begin{array}{c}\text { Maximum } \\
\text { depth }(\mathrm{m})\end{array}$ \\
\hline \multirow{3}{*}{$\begin{array}{l}\text { Eastmain River } \\
\text { watershed }\end{array}$} & $\begin{array}{l}\text { Eastmain 1 reservoir } \\
\text { (created in 2005) }\end{array}$ & $52.19^{\circ} \mathrm{N}$ & $75.05^{\circ} \mathrm{W}$ & 603 & 2.3 & 16 & 63 \\
\cline { 2 - 9 } & Mistumis Lake & $52.16^{\circ} \mathrm{N}$ & $76.16^{\circ} \mathrm{W}$ & 4 & N/A & 5 & 12 \\
\cline { 2 - 9 } & Clarkie Lake & $52.23^{\circ} \mathrm{N}$ & $75.47^{\circ} \mathrm{W}$ & 24 & N/A & 6 & 18 \\
\hline
\end{tabular}

surface) and diffusion and bubbling in the river downstream of the generating station (Soumis et al., 2004; Roehm and Tremblay, 2006). Tremblay et al. (2005), Tremblay and Bastien (2009) and Tremblay et al. (2010) have shown that in Eastmain 1 reservoir, diffusive emissions comprising over $95 \%$ of total gross emissions, with degassing and bubble emissions representing less than $5 \%$ of the total. Therefore, in this study we have focused on diffusive flux.

In northern temperate and boreal regions, seasonal variations in diffuse emissions of carbon $\left(\mathrm{CO}_{2}\right.$ and $\left.\mathrm{CH}_{4}\right)$ from freshwater ecosystems are difficult to measure directly, because the ice cover during winter prevents flux measurements from being taken with floating chambers. Also, continuous monitors, such as eddy covariance towers, are still controversial, because of possible interference with, for example, the surrounding forest (MacIntyre et al., 1995; Eugster et al., 2003). However, in such climates, temporal variation is crucial information for annual carbon budget estimation, since it is commonly recognized that, in certain conditions, $\mathrm{CO}_{2}$ and $\mathrm{CH}_{4}$ can accumulate under ice (Riera et al., 1999; Kortelainen et al., 2000; Striegl et al., 2001) and be released as diffusive flux on spring ice break-up (Michmerhuizen and Striegl, 1996; Huttunen et al., 2004; Duchemin et al., 2006).

The objectives of our study were to (1) present a follow-up from 2006 to 2008 of GHG partial pressures and flux measured at different seasons in the Eastmain River watershed area; (2) address the question of gas accumulation under ice cover (increase in partial pressure) in both lakes and reservoir by comparing results of winter and summer field surveys; and (3) propose a way to estimate annual gross diffusive GHG flux from seasonal field campaign measurements. We present a comparison of gross diffusive emissions from Eastmain 1 reservoir and two nearby lakes to document the effect of anthropogenic reservoir creation on aquatic GHG emissions (as performed by Huttunen et al., 2003, for European reservoirs).

\section{Methodology}

\subsection{Study sites}

Eastmain 1 reservoir, Mistumis Lake and Clarkie Lake were sampled in the Eastmain River watershed (Table 1), in the boreal zone, northwestern Québec, Canada (Fig. 1). Within this region, mean monthly temperatures vary between $-23^{\circ} \mathrm{C}$ and $14{ }^{\circ} \mathrm{C}$, and total rainfall and total snow precipitation are up to $430 \mathrm{~mm}$ and $260 \mathrm{~mm}$, respectively. The Eastmain River's catchment is dominated by coniferous forest, shallow podzolic and peat soils, and igneous bedrock. The aquatic systems studied are oligotrophic, with an overall low primary production (Planas et al., 2005). They are partially to totally covered by ice from about 15 December to 15 May (according to Hydro-Québec surveys). For safety reasons, winter field surveys could only be done between early January and the end of March, when the ice was at least $20 \mathrm{~cm}$ thick.

Eastmain 1 reservoir was four years old at the time of the study, and it has been observed that it can take around 10 years after reservoir creation for the labile flooded organic matter to decompose and for diffusive $\mathrm{CO}_{2}$ flux to return to levels observed in natural lakes before reservoir creation (Chartrand et al., 1994; Tremblay et al., 2005). Accordingly, higher $\mathrm{CO}_{2}$ emissions were expected in Eastmain 1 reservoir than in the natural lakes studied.

Sampling dates between 2006 and 2008 and the number of sampling stations (visited once per sampling period) for each water body are described in Table 2. When Eastmain 1 reservoir was created, three types of ecosystems were flooded: forest $(57 \%)$, lakes and river (25\%), and peatlands (18\%). For the purposes of the Eastmain 1 reservoir GHG survey program, a large number of sampling stations were chosen to cover the spatial variability of the flooded landscape (Fig. 1, all campaigns together) and to allow net emission calculation (Tremblay et al., 2010). At least three sampling stations were chosen above each flooded lake or peatland of interest. As well, several sampling stations were chosen above the flooded riverbed. Two or three sampling stations were chosen per lake studied, with one station in deep water. Locations remained the same during each field survey. The number of stations sampled depended on weather conditions (especially 


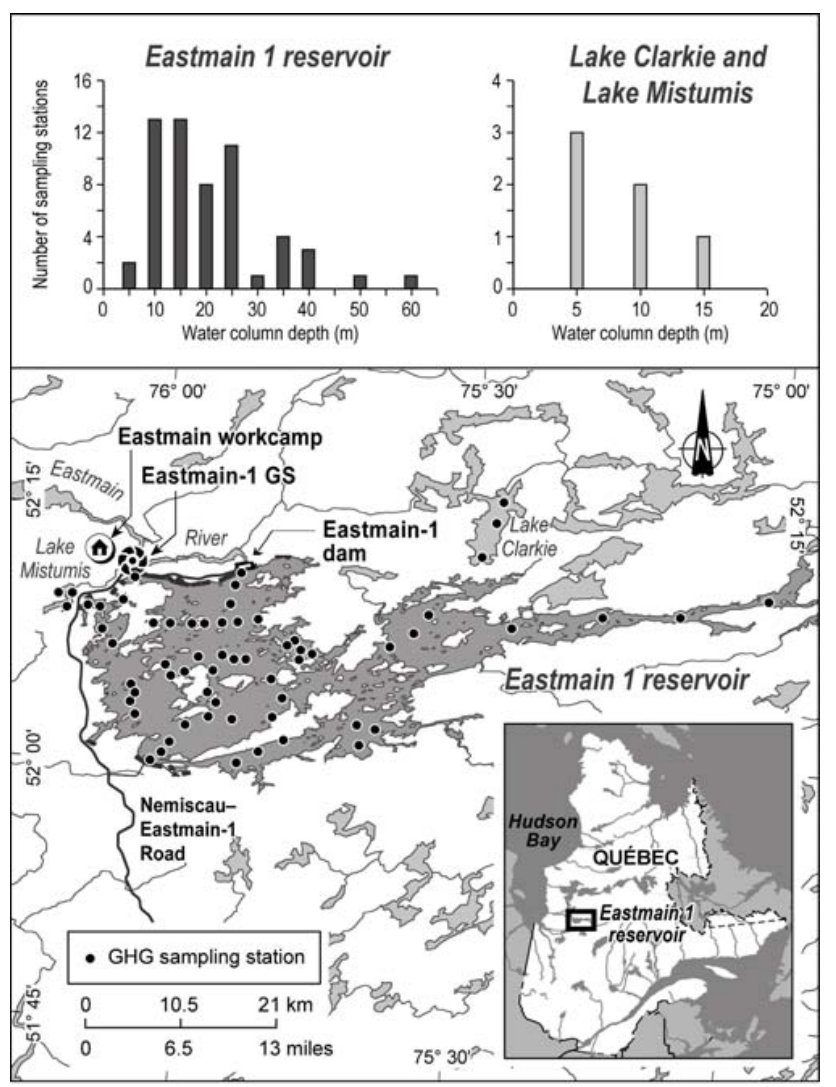

Fig. 1. Map of sampling stations in Eastmain River watershed; graphs representing distribution of sampling depths.

in winter), with at least one station per sampling section (e.g., one flooded lake of interest).

Temperature and dissolved oxygen profiles determined during the field surveys showed that there was no water column stratification (neither thermocline nor oxycline), whatever the season (Demarty et al., 2008)

\subsection{Spatial coverage of $\mathrm{CO}_{2}$ and $\mathrm{CH}_{4}$ partial pressures}

The partial pressure of $\mathrm{CO}_{2}$ and $\mathrm{CH}_{4}\left(p \mathrm{CO}_{2}\right.$ and $\left.p \mathrm{CH}_{4}\right)$ was measured at the water surface $(0.1 \mathrm{~m})$ for all sampling stations at Eastmain 1 reservoir, Mistumis Lake and Clarkie Lake. Also, at Eastmain 1 reservoir, $p \mathrm{CO}_{2}$ and $p \mathrm{CH}_{4}$ profiles were produced for 11 sampling stations in March 2007, 17 stations in January 2008, 2 stations in March 2008, 13 stations in July 2008 and 13 stations in September 2008. Stations were chosen to represent the reservoir's spatial variability and according to weather conditions. At Mistumis Lake, $p \mathrm{CO}_{2}$ and $p \mathrm{CH}_{4}$ profiles were produced at one station during each field survey. Three sampling depths were chosen according to the station's water depth, with one station at the bottom of the water column and the others at one third and two thirds of the water column's depth.
To measure $p \mathrm{CO}_{2}$, water was sampled with a peristaltic pump and surface water $p \mathrm{CO}_{2}$ was measured in situ with a nondispersive infrared (NDIR) sensor (EGM-4 manufactured by PP Systems) coupled with a gas exchanger (Membrana Celgard). Ten consecutive measurements (one per minute) were averaged to obtain the $p \mathrm{CO}_{2}$ at each station (mean variation coefficient of $1.3 \%$ ).

To determine $p \mathrm{CH}_{4}$, three $30-\mathrm{mL}$ water samples were collected in 60-mL polypropylene syringes from each depth and kept chilled in a dark cooler for transport to the laboratory. There, $30 \mathrm{~mL}$ of nitrogen gas $\left(\mathrm{N}_{2}\right)$ was added. Water and $\mathrm{N}_{2}$ were equilibrated by shaking the syringe vigorously for two minutes. Partial pressure of $\mathrm{CH}_{4}$ in the headspace $\left(p \mathrm{CH}_{4}\right.$ HS) was quantified by means of a gas chromatograph (with a flame ionization detector) within $24 \mathrm{~h}$. Partial pressure before equilibration $\left(\mathrm{CCH}_{4} f\right)$ was determined using Eqs. (1) and (2):

$p \mathrm{CH}_{4} f=\frac{\left(p \mathrm{CH}_{4} \mathrm{HS} \times K_{\mathrm{HEq}} .\right)+\left(\mathrm{HSR} \times \frac{\left(p \mathrm{CH}_{4} \mathrm{HS}-p \mathrm{CH}_{4} i\right)}{V_{\mathrm{m}}}\right)}{K_{\mathrm{H} \text { Sample }}}$

where HSR is the headspace ratio (here equal to 1 ); $p \mathrm{CH}_{4} i$ is equal to 0 , since the only gas in the air inside the syringe before equilibration was $\mathrm{N}_{2} ; V_{\mathrm{m}}$ is the molar volume (according to Avogadro's law); $K_{\mathrm{HEq}}$ and $K_{\mathrm{H}}$ Sample are the gas partition constants at equilibrium $\left(20^{\circ} \mathrm{C}\right)$ and at sampling temperature, respectively, calculated according to Lide (2007):

$$
\begin{aligned}
& \ln K_{\mathrm{H}}\left(\mathrm{CH}_{4}\right)=-115.6477+\frac{155.5756}{\left(T_{\mathrm{K}} / 100\right)}+65.2553 \\
& \quad \times \ln \left(\frac{T_{\mathrm{K}}}{100}\right)-6.1698 \times\left(\frac{T_{\mathrm{K}}}{100}\right)
\end{aligned}
$$

where $T_{\mathrm{K}}$ is the temperature in kelvin. $K_{\mathrm{H}}\left(\mathrm{CH}_{4}\right)$ is in molar fraction $\mathrm{atm}^{-1}$ (Lide, 2007) but converted to $\mathrm{mole}^{-1} \mathrm{~atm}^{-1}$ using the following factor, $\left(\frac{1000 \mathrm{gL}^{-1}[\text { water density] }}{18.0153 \mathrm{~g} / \text { mole [water molecular weight }]}\right)$. The field $\mathrm{pCH}_{4}$ was obtained by averaging the results from three sampling syringes.

To obtain mean profiles of the water bodies, for each field surveys of Eastmain 1 reservoir, results from same sampling depth were averaged (different sampling station were thus considered as replicates at the reservoir/lake scale). This method of averaging data gives a rough snapshot of the state of the whole reservoir, but does not provide a fine description of the processes at work. We found that the means calculated at each sampling depth had an average coefficient of variation of $20 \%$. At Mistumis Lake, three stations were sampled and a GHG profile was produced at a single station (explaining the absence of an error bar in Fig. $4 a$ and c). 
Table 2. Sampling periods and number of GHG (and water quality for Eastmain 1 reservoir and Mistumis Lake) sampling stations for each water body studied.

\begin{tabular}{lllccc}
\hline & & & \multicolumn{3}{c}{ Number of sampling stations } \\
\cline { 4 - 6 } System & Sampling periods & Ice/Ice-free & $\begin{array}{c}\text { Eastmain 1 } \\
\text { reservoir }\end{array}$ & $\begin{array}{c}\text { Mistumis } \\
\text { Lake }\end{array}$ & $\begin{array}{c}\text { Clarkie } \\
\text { Lake }\end{array}$ \\
\hline \multirow{5}{*}{ Eastmain River } & 10-22 July 2006 & Ice-free & 41 & 3 & 2 \\
& 18 September-4 October 2006 & Ice-free & 42 & & \\
& 20-27 March 2007 & Ice & 39 & 3 & \\
& 5-21 July 2007 & Ice-free & 38 & 3 & 3 \\
& 14-26 January 2008 & Ice & 42 & 3 & 3 \\
& 26 March-5 April 2008 & Ice & 35 & 3 & 2 \\
& 3-22 July 2008 & Ice-free & 57 & 3 & 3 \\
& 15-22 September 2008 & Ice-free & 27 & 3 & 2
\end{tabular}

\subsection{Time series of $p \mathrm{CO}_{2}$ and $p \mathrm{CH}_{4}$ and temperature from Eastmain 1 reservoir}

Automated GHG systems (monitors) have been in place at Eastmain-1 generating station (GS) since 2006 to obtain GHG partial pressure time series. The continuous gas monitor is modeled after Carignan's design (1998) and built of commercial components. Every three hours, $\mathrm{CO}_{2}$ and $\mathrm{CH}_{4}$ are measured by two different sensors (LICOR LI-820 NDIR sensor and Neodym Panterra metal oxide semiconductor sensor, respectively) on a gas stream that has been equilibrated with the source water (Demarty et al., 2009). Measurements taken at a single sampling station with monitors installed in the GS (Québec and Manitoba, Demarty et al., 2009) have been shown to be representative of conditions in the whole reservoir. Generally, no $\mathrm{CH}_{4}$ accumulation under ice cover has been observed, contrary to $\mathrm{CO}_{2}$ (see Fig. 2 for the example of results from Eastmain-1 GS GHG monitor). Trends observed from GHG monitoring measurements were used to determine the trends between field surveys and to calculate maximum $p \mathrm{CO}_{2}$ reached before ice break-up and flux accordingly (Fig. 3 and Sects. 3.4 and 3.5).

\subsection{Calculation of $\mathrm{CO}_{2}$ and $\mathrm{CH}_{4}$ flux}

We calculated mean $p \mathrm{CO}_{2}$ and $p \mathrm{CH}_{4}$ for ice-free periods, and thereby estimated mean flux using corresponding mean water temperatures (data from automated systems at Eastmain-1 GS) and wind speeds (data from Nemiscau Airport meteorological station, $69 \mathrm{~km}$ away from the study area).

According to MacIntyre et al. (2005), flux calculations require conversion of partial pressures in concentration. $\mathrm{CO}_{2}$ water concentration and $\mathrm{CH}_{4}$ water concentration $\left(\mathrm{CO}_{2} \mathrm{Wc}\right.$ and $\mathrm{CH}_{4} \mathrm{wc}$, respectively) were calculated from $p \mathrm{CO}_{2}$ $\left(\mathrm{CO}_{2} \mathrm{wp}\right.$ ) and $p \mathrm{CH}_{4}\left(\mathrm{CH}_{4} \mathrm{wp}\right.$ ), using Eqs. (3) and (4) (Morel, 1982; Anderson, 2002):

$\mathrm{CO}_{2} \mathrm{wc}=K_{\mathrm{H}} \times \mathrm{CO}_{2} \mathrm{wp}$

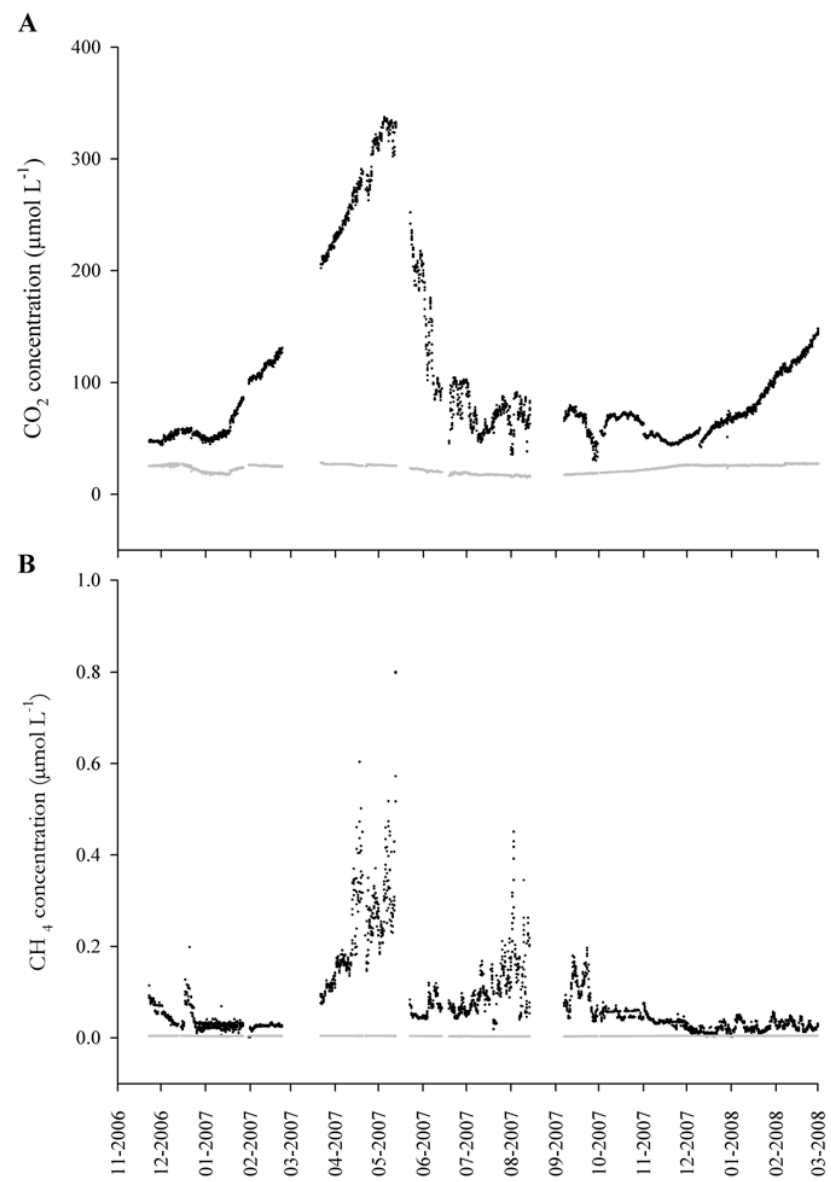

Fig. 2. Time series of $\mathrm{CO}_{2}$ and $\mathrm{CH}_{4}$ concentrations measured by GHG monitors at Eastmain-1 generating station, 2006-2008. 


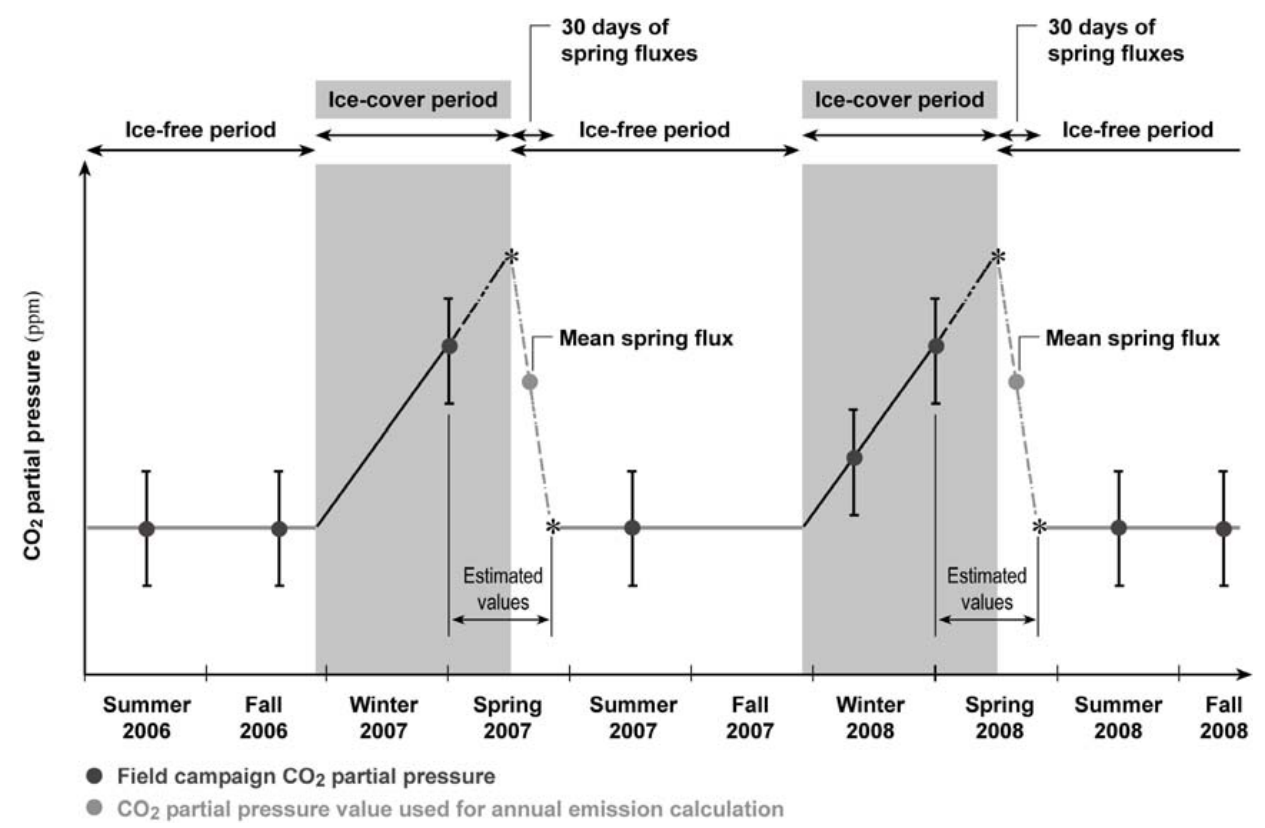

Fig. 3. Schematic representation of estimated annual emissions based on seasonal field surveys for $\mathrm{CO}_{2}$-supersaturated systems. Dotted line represents partial pressure of $\mathrm{CO}_{2}$ at water surface in equilibrium with atmosphere.

$\mathrm{CH}_{4} \mathrm{wc}=K_{\mathrm{H}} \times \mathrm{CH}_{4} \mathrm{wp}$

with $K_{\mathrm{H}}\left(\mathrm{CO}_{2}\right)$ and $K_{\mathrm{H}}\left(\mathrm{CH}_{4}\right)$ determined according to Eqs. (5) and (2), respectively:

$$
\begin{array}{r}
\ln K_{\mathrm{H}}\left(\mathrm{CO}_{2}\right)=-58.0931+90.5069 \\
\times\left(\frac{100}{T_{\mathrm{K}}}\right)+22.294 \times \ln \left(\frac{T_{\mathrm{K}}}{100}\right)
\end{array}
$$

where $K_{\mathrm{H}}\left(\mathrm{CO}_{2}\right)$ is the gas partition constant of $\mathrm{CO}_{2}$ in water at sampling temperature, expressed in mole $\mathrm{L}^{-1} \mathrm{~atm}^{-1}$, and $T_{\mathrm{K}}$ is the temperature in kelvin (Weiss, 1974).

Then, $\mathrm{CO}_{2}$ and $\mathrm{CH}_{4}$ flux was calculated using Eq. (6) (MacIntyre et al., 1995),

Flux $=k_{x}(\mathrm{Cw}-\mathrm{Ca})$

with $\mathrm{Ca}$ being the gas concentration in water exposed to the atmosphere (385 ppm for $\mathrm{CO}_{2}$, NOAA, October 2008; and 1.745 ppm for $\mathrm{CH}_{4}$, Houghton et al., 2001),

$k_{x}$ being the mass transfer coefficient $\left(\mathrm{cm} \mathrm{h}^{-1}\right)$ :

$k_{x}=k_{600}\left(\frac{\mathrm{Sc}}{600}\right)^{-x}$

where $x$ is equal to 0.66 for wind speed $\leq 3 \mathrm{~m} \mathrm{~s}^{-1}$ and is equal to 0.5 for wind speed $>3 \mathrm{~m} \mathrm{~s}^{-1}$; Sc is the Schmidt number for $\mathrm{CO}_{2}$ or $\mathrm{CH}_{4}$, which is dependent on temperature $(T$, in kelvin) according to Eqs. (8) and (9) (Wanninkhof, 1992):

$$
\begin{aligned}
& \mathrm{Sc}\left(\mathrm{CO}_{2}\right)=1911.1-118.11 T+3.4527 T^{2}-0.04132 T^{3} \\
& \mathrm{Sc}\left(\mathrm{CH}_{4}\right)=1897.8-114.28 T+3.2902 T^{2}-0.039061 T^{3}
\end{aligned}
$$

and $k_{600}$ is estimated from the wind speed, according to Cole and Caraco (1998):

$k_{600}=2.07+\left(0.215 \times U_{10}^{1.7}\right)$.

The flux obtained from Eq. (6) is converted from moles to grams. The GHG flux can thus be calculated by adding the $\mathrm{CO}_{2}$ and $\mathrm{CH}_{4}$ fluxes in $\mathrm{CO}_{2}$ eq (Eq. (11), using the global warming potential of 25 for $\mathrm{CH}_{4}$, Forster et al., 2007):

GHG Flux $\left(\mathrm{CO}_{2}\right.$ eq $)=\mathrm{CO}_{2}$ flux $+25 \times\left(\mathrm{CH}_{4}\right.$ flux $)$

\section{Results}

\subsection{Interannual variation and comparison of reservoir and nearby lakes}

Under the assumption of an atmospheric $\mathrm{CO}_{2}$ partial pressure of $385 \mathrm{ppm}$ (NOAA, 2008), we observed that the three water bodies studied are supersaturated in $\mathrm{CO}_{2}$, whatever the season, with a $p \mathrm{CO}_{2}$ one (Clarkie Lake, September 2008) to seven (Eastmain 1 reservoir, March 2007) times higher than the atmospheric equilibration partial pressure (Table 3).

Mean summer water surface $p \mathrm{CO}_{2}$ measured at Eastmain 1 reservoir decreased from 2006 to 2008, with 2205 ppm, 1269 ppm and 1126 ppm in 2006, 2007 and 2008, respectively. Mean winter water surface $p \mathrm{CO}_{2}$ was higher and not significantly different in 2007 and 2008 (2798 ppm in March 2007 and 2529 ppm in March 2008; t-test, $p>.05$ ). So a winter increase in partial pressure does not appear to 
Table 3. Mean surface $p \mathrm{CO}_{2}$ and $p \mathrm{CH}_{4}$ ( \pm standard deviation) measured at Eastmain 1 reservoir, Mistumis Lake, Clarkie Lake, Robert Bourassa reservoir, Duncan Lake and Yasinski Lake. The number of replicates corresponds to the number of sampling stations given in Table 2 .

\begin{tabular}{lcccccr}
\hline & \multicolumn{2}{c}{ Eastmain 1 reservoir } & \multicolumn{2}{c}{ Mistumis Lake } & \multicolumn{2}{c}{ Clarkie Lake } \\
\cline { 2 - 6 } Field surveys & $p \mathrm{CO}_{2}$ & $p \mathrm{CH}_{4}$ & $p \mathrm{CO}_{2}$ & $p \mathrm{CH}_{4}$ & $p \mathrm{CO}_{2}$ & $p \mathrm{CH}_{4}$ \\
\cline { 2 - 6 } & \multicolumn{7}{c}{$\mathrm{ppm}$} \\
\hline July 2006 & $2230 \pm 563$ & $125 \pm 151$ & $565 \pm 30$ & $33 \pm 5$ & $558 \pm 13$ & - \\
September 2006 & $2181 \pm 485$ & $83 \pm 65$ & - & - & - & - \\
March 2007 & $2798 \pm 708$ & $20 \pm 31$ & $1441 \pm 47$ & $8 \pm 2$ & - & - \\
July 2007 & $1333 \pm 317$ & - & $568 \pm 47$ & - & $496 \pm 42$ & - \\
January 2008 & $1211 \pm 194$ & $40 \pm 82$ & $856 \pm 25$ & $17 \pm 2$ & $716 \pm 31$ & $11 \pm 1$ \\
March 2008 & $2529 \pm 796$ & $287 \pm 982$ & $1533 \pm 268$ & $19 \pm 9$ & $975 \pm 171$ & $13 \pm 2$ \\
July 2008 & $1025 \pm 361$ & $58 \pm 56$ & $620 \pm 73$ & $25 \pm 19$ & $507 \pm 34$ & $9 \pm 2$ \\
September 2008 & $1340 \pm 459$ & $38 \pm 38$ & $454 \pm 18$ & $24 \pm 7$ & $425 \pm 4$ & $17 \pm 5$ \\
\hline
\end{tabular}

affect summer trends, which indicate that the limiting processes for $\mathrm{CO}_{2}$ production are not the same in winter (temperature limits the decomposition of organic matter) and in summer (organic matter availability would be the limiting factor, decreasing over time). For Mistumis and Clarkie Lakes, summer and winter values were not different from year to year (ANOVA and t-test, $p>.05$ ).

Winter and summer surface $p \mathrm{CO}_{2}$ measured at Eastmain 1 reservoir are higher than $p \mathrm{CO}_{2}$ measured at the two lakes nearby (ANOVA, $p<.05$ ).

There were no significant differences between $p \mathrm{CH}_{4}$ measured at the reservoir and nearby lake surfaces in the different sampling periods, because of the high spatial variability observed in the reservoir (ANOVA, $p>.05$ ).

\subsection{Dissolved gas profiles in Eastmain River watershed}

Figure 4 shows the seasonal $p \mathrm{CO}_{2}$ and $p \mathrm{CH}_{4}$ profiles for Eastmain 1 reservoir and Mistumis Lake. For Mistumis Lake, an increase in $p \mathrm{CO}_{2}$ with depth was observed for under-ice measurements, reflecting winter $\mathrm{CO}_{2}$ buildup (Fig. 4a). There was a general increase in $p \mathrm{CO}_{2}$ with depth at Eastmain 1 reservoir, whatever the season, with the greatest difference between surface and bottom observed in March 2007 and 2008 (Fig. 4b), reflecting $\mathrm{CO}_{2}$ accumulation under the ice.

At Mistumis Lake, there was no trend in $p \mathrm{CH}_{4}$ with depth, except in September 2008 (Fig. 4c), where $p \mathrm{CH}_{4}$ increased from $20 \mathrm{ppm}$ at $7.5 \mathrm{~m}$ to $152 \mathrm{ppm}$ at $9 \mathrm{~m}$. Unfortunately, no other summer or fall data are available from a depth of $9 \mathrm{~m}$, preventing us from reaching any conclusion about the potential recurrence of such an event.

At Eastmain 1 reservoir, there was no trend in $\mathrm{pCH}_{4}$ with depth, except in March 2007 (Fig. 4d). During that survey, we measured $p \mathrm{CH}_{4}$ from the surface to a depth of $21 \mathrm{~m}$. Most of the $p \mathrm{CH}_{4}$ profiles gave similar values from surface to bottom, with no $\mathrm{CH}_{4}$ accumulation under the ice, but the trends were different at three of the seven sampling stations. Indeed, for stations KP 45-3 (at depths of $10 \mathrm{~m}$ and $13 \mathrm{~m}$ ), KP 260-4 (at $21 \mathrm{~m}$ only) and Tower-3 (at $21 \mathrm{~m}$ only), high $\mathrm{pCH}_{4}$ was measured (Fig. 4d), corresponding to low to very low dissolved oxygen saturation $(50 \%, 15.5 \%, 16.7 \%$ and $21.6 \%$, respectively, data from temperature and dissolved gas profiles not shown), thus suggesting $\mathrm{CH}_{4}$ accumulation in deep zones. We cannot confirm a regular under-ice buildup of $\mathrm{CH}_{4}$, since January 2008 profiles at the same stations showed no increase with depth and the same profiles are not available for the March 2008 survey. However, low dissolved oxygen saturation seen in March 2008 below a depth of $20 \mathrm{~m}$ (data not shown) may have led to similar favorable conditions for $\mathrm{CH}_{4}$ production in deep zones. For the reservoir as a whole, our results showed that, as at Mistumis Lake, high values measured at depth are not reflected by the overall surface $p \mathrm{CH}_{4}$ (surface $p \mathrm{CH}_{4}$ measured at 39 stations in March 2007), also suggesting a $\mathrm{CH}_{4}$ degradation along the water column. In March 2008, three stations (among the 34 where $\mathrm{pCH}_{4}$ measurements were done) showed very high surface $p \mathrm{CH}_{4}$ (1442 ppm, $2221 \mathrm{ppm}$ and $5439 \mathrm{ppm}$ ), leading to the high mean surface partial pressure observed in Fig. 4d (303 ppm, standard deviation \pm 1009 ); without these data the mean $\mathrm{pCH}_{4}$ would be $41 \mathrm{ppm}$, which is not significantly different from the surface $p \mathrm{CH}_{4}$ observed during the other survey. Accordingly, we will consider that there was no $\mathrm{CH}_{4}$ accumulation under ice cover for either Eastmain 1 reservoir or Mistumis Lake, as already suggested by the GHG monitor data.

\subsection{Estimate of maximum dissolved $p \mathrm{CO}_{2}$ reached before ice break-up}

$\mathrm{CO}_{2}$ accumulation under ice cover has been observed in Eastmain 1 reservoir, Mistumis Lake and Clarkie Lake: 

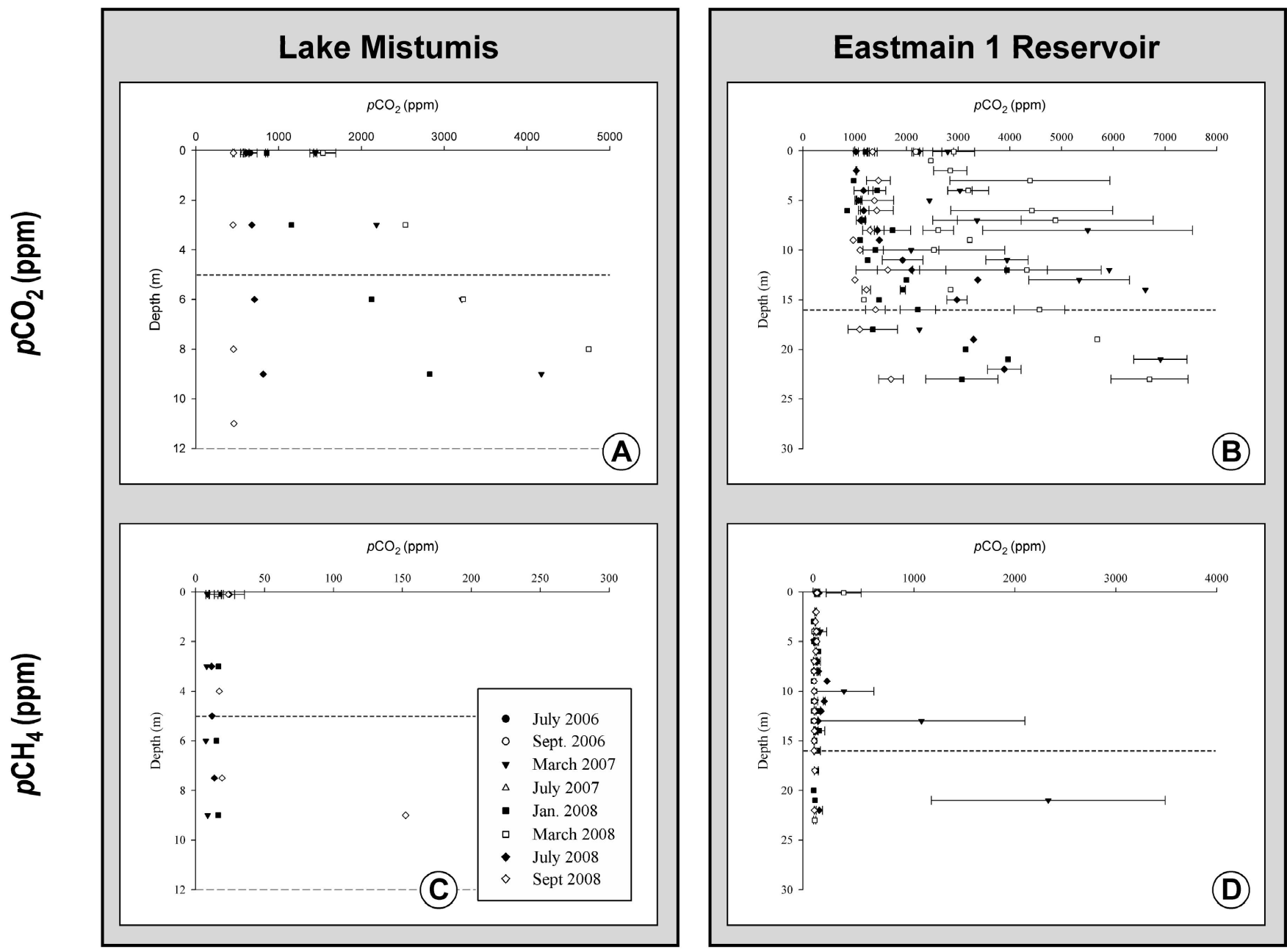

Fig. 4. Mean profiles of $p \mathrm{CO}_{2}$ and $p \mathrm{CH}_{4}$ for Eastmain 1 reservoir and Mistumis Lake. Bars represent standard errors. Dashed lines represent maximum depth (for Mistumis Lake) and dotted lines represent mean depth.

Table 4. Daily rates of under-ice $p \mathrm{CO}_{2}$ increase and maximum potential $p \mathrm{CO}_{2}$ reached by 15 May at study sites.

\begin{tabular}{lccccccc}
\hline Study site & $n$ & $\begin{array}{c}\text { Springtime daily rates } \\
\text { of } p \mathrm{CO}_{2} \text { increase ppm d }\end{array}$ & $\begin{array}{c}\mathrm{SD} \\
\mathrm{ppm} \mathrm{d}^{-1}\end{array}$ & & $R^{2}$ & \multicolumn{2}{c}{$\begin{array}{c}\text { Potential } p \mathrm{CO}_{2} \text { reached. } \\
\text { 15 May (ppm) }\end{array}$} \\
\cline { 5 - 8 } & & & & & Mean & Min. & Max. \\
\hline Eastmain 1 res., 2007 & 122 & 7.91 & 16.79 & 0.18 & 3154 & 0 & 5168 \\
Eastmain 1 res., 2008 & 116 & 16.80 & 14.26 & 0.59 & 3285 & 1574 & 4996 \\
Mistumis Lake, 2007 & 7 & 11.68 & 1.02 & 0.99 & 1967 & 1844 & 2089 \\
Mistumis Lake, 2008 & 9 & 10.95 & 5.60 & 0.83 & 2026 & 1354 & 2698 \\
Clarkie Lake, 2008 & 8 & 4.90 & 4.00 & 0.65 & 1196 & 1085 & 2266 \\
\hline
\end{tabular}




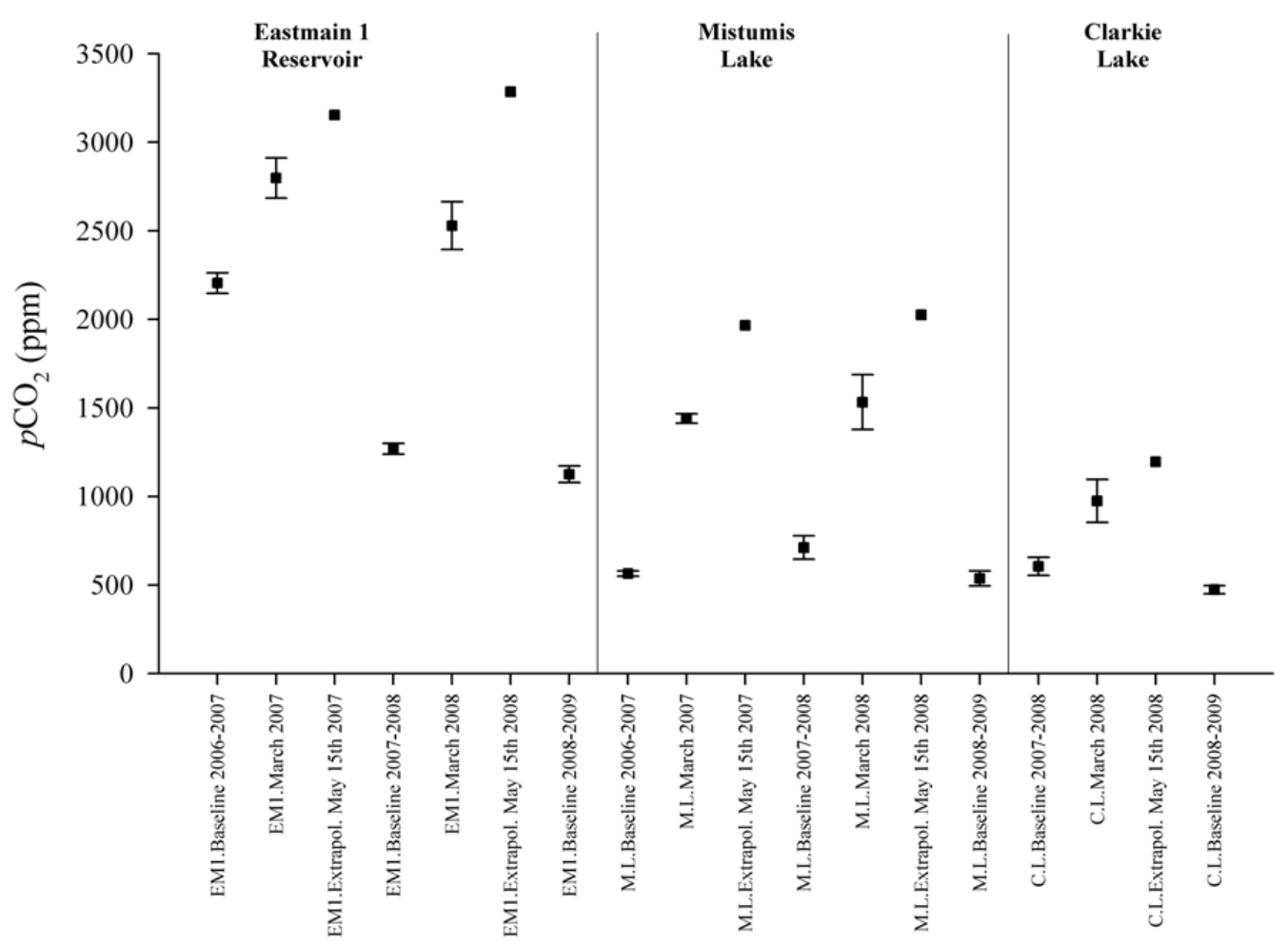

Fig. 5. Measured and extrapolated partial pressure of $\mathrm{CO}_{2}$ for different systems studied. Bars represent standard errors. Baseline points represent mean values during ice-free periods.

spring values (i.e., in March-April) are clearly higher than what was measured during the other sampling period (ANOVA, $p<.05$; Table 4 and Fig. 5), whereas no differences in summer, fall and early winter (before January) mean dissolved $p \mathrm{CO}_{2}$ was observed (ANOVA, $p>.05$ ). Taken together, the later data thus represent the baseline $p \mathrm{CO}_{2}$ of the year (Fig. 5). A higher dissolved $p \mathrm{CO}_{2}$ is observed in March than in January, and a linear increase of dissolved $p \mathrm{CO}_{2}$ is expected under the ice cover from January to May (Fig. 3). Linear regressions between baseline $p \mathrm{CO}_{2}$ values and March $p \mathrm{CO}_{2}$ values were then made to calculate the under-ice daily rate of $p \mathrm{CO}_{2}$ increase ( 75 days between the two sampling dates, 15 January and 30 March; Table 4). Taking the date of 15 May as the beginning of the spring emission period (based on observations from automated systems), we thus estimated potential $p \mathrm{CO}_{2}$ before the ice break-up (Table 4). From these calculations, it is clear that Eastmain 1 reservoir tends to present the highest $p \mathrm{CO}_{2}$ before the spring emission period.

\subsection{Estimate of potential spring gross diffusive GHG emissions}

The method used to estimate the potential spring gross diffusive emissions is shown in Fig. 3. Depending on when the ice break-up began (as recorded by the ice survey program over the last 30 years), the spring emission period in the studied area was assumed to last around one month, from 15 May to 15 June. Between these dates, flux was assumed to follow a linear trend. Maximum potential partial pressures were used to calculate the maximum potential flux at the beginning of the spring emission period, and baseline partial pressures were used to calculate potential flux during the following period (summer and fall; Table 5). Averaging these two fluxes, we obtained a mean daily spring flux, which was used to compute an annual carbon budget. Accordingly, over one month, mean GHG flux calculated ranged between $37 \mathrm{gCO}_{2} \mathrm{eq} \mathrm{m}^{-2}$ (Clarkie Lake) and $147 \mathrm{gCO}_{2} \mathrm{eq} \mathrm{m}^{-2}$ (Eastmain 1 reservoir, 2008).

\subsection{Annual cumulative diffusive flux}

The annual $\mathrm{CO}_{2}$ flux was calculated as the sum of the daily fluxes between two spring emission periods (for example, 15 May 2007 to 15 May 2008): we added 31 days of mean spring flux (see Table 5), 214 days of mean ice-free period flux (summer, fall and beginning of winter) and 120 days without flux (ice-cover period). The resulting annual $\mathrm{CO}_{2}$ emissions for the water bodies studied are presented in $\mathrm{Ta}-$ ble 6. Spring $\mathrm{CO}_{2}$ flux represented $23 \%$ (Eastmain 1 reservoir) to $52 \%$ (Mistumis Lake) of annual diffusive $\mathrm{CO}_{2}$ emissions, and spring $\mathrm{CH}_{4}$ flux represented 5\% (Eastmain 1 reservoir) to $18 \%$ (Clarkie Lake) of annual diffusive $\mathrm{CH}_{4}$ emissions. Clarkie Lake had the lowest diffusive emissions. For 
Mistumis Lake and Eastmain 1 reservoir, 2008-2009 emissions were lower than in the previous year. As this study is part of a long-term monitoring program, the observed trend merits further discussion with regard to he future data.

\section{Discussion}

This study is the first to provide a multiannual estimation of spring diffusive GHG flux for both reservoirs and nearby lakes.

Comparisons of reservoirs with nearby lakes are commonly found in the literature (Åberg et al., 2004; Harrison et al., 2009). The limnological features of reservoirs more than 10 years old are generally comparable to those of lakes in the same region (Schetagne, 1994). Old reservoirs also behave like lakes in terms of GHG emissions (Demarty et al., 2008). References are needed when studying the evolution of newly impounded reservoirs such as Eastmain 1. In the case of the Eastmain 1 reservoir GHG monitoring program, the emissions of several lakes were studied before the reservoir was created, and Mistumis Lake and Clarkie Lake were found to be representative of lakes in the area (Blais and Tremblay, 2007). Theyhave therefore been chosen as references for studies after creation of the reservoir.

\subsection{Choice of partial pressures used to estimate spring flux}

The potential spring GHG flux of lakes and reservoirs is commonly calculated as the difference between the amount of accumulated gas (using the potential GHG storage of water bodies to obtain the concentration per square metre) and the amount of gas at atmospheric equilibrium (i.e., $385 \mathrm{ppm}$ for $\mathrm{CO}_{2}$, 1998; Striegl et al., 2001; Huttunen et al., 2004; Duchemin et al., 2006). But many lakes (Cole et al., 1994; Del Giorgio et al., 1999; Duarte and Prairie, 2005) and reservoirs (Tremblay et al., 2005; Demarty et al., 2009) around the world are supersaturated with $\mathrm{CO}_{2}$, meaning that the partial pressure of $\mathrm{CO}_{2}$ is generally above atmospheric partial pressure for most of the year. It is therefore misleading to consider that the partial pressure of dissolved GHG will reach equilibrium with the atmosphere after spring emissions. Since the difference between the highest partial pressure of dissolved GHG reached under ice cover and equilibrium is greater than the actual partial pressure measured in late spring (see Fig. 3), the misconception leads to overestimates of spring (and annual) flux. That is why, in this paper, we felt that using the difference between partial pressure at the water surface at the beginning and end of the ice-cover period was a better method of estimating spring diffusive flux.

\subsection{Assumptions regarding trends in partial pressure}

Two main assumptions were made regarding the estimation of maximum partial pressure of dissolved gases before ice break-up. First, we averaged the results of the ice-free period (summer, fall and end of December) to obtain a baseline flux, and then computed a conservative annual flux. Because of the lack of data between September and ice cover, we could not examine the importance of the fall turnover, which is known to affect $\mathrm{CO}_{2}$ and $\mathrm{CH}_{4}$ flux. However, for Eastmain 1 reservoir, data from September 2008 (Fig. 4) showed that partial pressure of $\mathrm{CO}_{2}$ and $\mathrm{CH}_{4}$ did not increase with depth, so fall turnover should not have led to an increased flux; we consequently assumed that the use of an ice-free mean as baseline would be acceptable.

Second, we assumed a linear trend in $\mathrm{CO}_{2}$ accumulation under the ice from January until the beginning of the spring emission period and a linear decrease during spring. These trends rely on the results obtained from monitors that have been measuring $p \mathrm{CO}_{2}$ and $p \mathrm{CH}_{4}$ time series at Eastmain-1 GS since 2006 and at other Québec and Manitoba GS (Demarty et al., 2009). In that paper, the authors showed that annual estimates of diffusive emissions from Eastmain 1 reservoir calculated either from GHG monitor data (time series) or by sampling surveys gave comparable results. We therefore decided to use the trends observed in Eastmain 1 reservoir to compute annual emissions from water bodies unequipped with GHG monitors, such as lakes.

\subsection{Source of $\mathrm{CO}_{2}$ increase under ice cover}

We observed $\mathrm{CO}_{2}$ buildup under ice cover at both the reservoir and lakes under study. We did not perform any experiments to examine heterotrophic $\mathrm{CO}_{2}$ production under ice cover, but it is probably due to the bacterial decomposition of organic matter, rather than to an underground water source. To discuss this hypothesis, the spring daily rates of $\mathrm{CO}_{2}$ increase under ice cover presented in Table 4 were calculated in terms of concentration rather than partial pressure, that is, using Eqs. (1) and (4), assuming a surface temperature of $0.1^{\circ} \mathrm{C}$, based on field observations. Rates varied between 0.3 and $0.9 \mu \mathrm{gC} \mathrm{L}{ }^{-1} \mathrm{~h}^{-1}$ at Clarkie Lake and Eastmain 1 reservoir, respectively. In their review of respiration in lakes, Pace and Prairie (2005) summarize field observations of planktonic respiration, which varies between $0.4 \mu g \mathrm{CL}^{-1} \mathrm{~h}^{-1}$ and $81 \mu \mathrm{gCL} \mathrm{L}^{-1} \mathrm{~h}^{-1}$ (mean: $7.9 \mu \mathrm{gCL}^{-1} \mathrm{~h}^{-1}$ ); temperature is presented as an important factor influencing respiration rates. Interestingly, the under-ice rates of $\mathrm{CO}_{2}$ increase observed in our systems are comparable to the lower range reported by Pace and Prairie (2005). This strongly suggests that $\mathrm{CO}_{2}$ increases under ice are due to bacterial respiration under the influence of cold temperatures, concomitant with low primary production, which hides the respiration rate in warmer conditions. This hypothesis is supported by Striegl et al. (2001), who demonstrated that high dissolved $p \mathrm{CO}_{2}$ prior to ice melt 
Table 5. Spring $\mathrm{CO}_{2}, \mathrm{CH}_{4}$ and GHG flux. The beginning and end of the degassing periods are assumed to be around 15 May and 15 June, respectively.

\begin{tabular}{|c|c|c|c|c|c|c|c|}
\hline Study site & Degassing period & $\begin{array}{c}\mathrm{CO}_{2} \text { flux } \\
\left(\text { mmole } \mathrm{m}^{-2} \mathrm{~d}^{-1}\right)\end{array}$ & $\begin{array}{c}\mathrm{CH}_{4} \text { flux } \\
\left(\text { mmole } \mathrm{m}^{-2} \mathrm{~d}^{-1}\right)\end{array}$ & $\begin{array}{c}\text { Mean } \mathrm{CO}_{2} \\
\text { spring flux } \\
\left(\text { mmole } \mathrm{m}^{-2} \mathrm{~d}^{-1}\right)\end{array}$ & $\begin{array}{c}\text { Mean } \mathrm{CH}_{4} \\
\text { spring flux } \\
\left(\text { mmole } \mathrm{m}^{-2} \mathrm{~d}^{-1}\right)\end{array}$ & $\begin{array}{c}\text { Mean GHG } \\
\text { spring flux } \\
\left(\mathrm{mmolCO}_{2} \text { eq }^{-2} \mathrm{~d}^{-1}\right)\end{array}$ & $\begin{array}{c}\text { Total GHG } \\
\text { spring flux } \\
\left(\mathrm{gCO}_{2} \mathrm{eq} \mathrm{m}^{-2}\right)\end{array}$ \\
\hline \multirow{2}{*}{$\begin{array}{l}\text { Eastmain } 1 \\
\text { reservoir }\end{array}$} & $\begin{array}{l}\text { Beginning } 2007 \\
\text { End } 2007\end{array}$ & $\begin{array}{c}131 \\
40\end{array}$ & $\begin{array}{l}0.017 \\
0.017\end{array}$ & 86 & 0.017 & 86 & 117 \\
\hline & $\begin{array}{l}\text { Beginning } 2008 \\
\text { End } 2008\end{array}$ & $\begin{array}{c}173 \\
43\end{array}$ & $\begin{array}{l}0.059 \\
0.012\end{array}$ & 108 & 0.036 & 108 & 147 \\
\hline \multirow{2}{*}{$\begin{array}{l}\text { Mistumis } \\
\text { Lake }\end{array}$} & $\begin{array}{l}\text { Beginning } 2007 \\
\text { End } 2007\end{array}$ & $\begin{array}{l}75 \\
15\end{array}$ & $\begin{array}{l}0.010 \\
0.010\end{array}$ & 45 & 0.010 & 45 & 61 \\
\hline & $\begin{array}{l}\text { Beginning } 2008 \\
\text { End } 2008\end{array}$ & $\begin{array}{c}98 \\
9\end{array}$ & $\begin{array}{l}0.036 \\
0.049\end{array}$ & 53 & 0.043 & 53 & 73 \\
\hline $\begin{array}{l}\text { Clarkie } \\
\text { Lake }\end{array}$ & $\begin{array}{l}\text { Beginning } 2008 \\
\text { End } 2008\end{array}$ & $\begin{array}{c}49 \\
5\end{array}$ & $\begin{array}{l}0.023 \\
0.015\end{array}$ & 27 & 0.019 & 27 & 37 \\
\hline
\end{tabular}

Table 6. Ice-free period, spring and annual $\mathrm{CO}_{2}, \mathrm{CH}_{4}$ and $\mathrm{GHG}$ emissions for water bodies studied. Note that emissions from reservoirs are gross emissions.

\begin{tabular}{|c|c|c|c|c|c|c|c|c|c|c|}
\hline \multirow{3}{*}{$\begin{array}{l}\text { Study site } \\
\text { and period }\end{array}$} & \multicolumn{4}{|c|}{$\mathrm{CO}_{2}$} & \multicolumn{4}{|c|}{$\mathrm{CH}_{4}$} & \multicolumn{2}{|c|}{ GHG } \\
\hline & \begin{tabular}{l}
\multicolumn{1}{c}{ Ice-free } \\
period $\mathrm{CO}_{2}$ \\
emissions
\end{tabular} & $\begin{array}{c}\text { Spring } \mathrm{CO}_{2} \\
\text { emissions }\end{array}$ & $\begin{array}{c}\text { Annual } \mathrm{CO}_{2} \\
\text { emissions }\end{array}$ & $\begin{array}{l}\text { Spring flux/ } \\
\text { annual flux }\end{array}$ & \begin{tabular}{l}
\multicolumn{1}{c}{ Ice-free } \\
period $\mathrm{CH}_{4}$ \\
emissions
\end{tabular} & $\begin{array}{c}\text { Spring } \mathrm{CH}_{4} \\
\text { emissions }\end{array}$ & $\begin{array}{c}\text { Annual } \mathrm{CH}_{4} \\
\text { emissions }\end{array}$ & $\begin{array}{l}\text { Spring flux/ } \\
\text { annual flux }\end{array}$ & $\begin{array}{c}\text { Annual GHG } \\
\text { emissions }\end{array}$ & $\begin{array}{c}\mathrm{CO}_{2} \\
\text { contribution }\end{array}$ \\
\hline & & $\mathrm{mmol} \mathrm{m}^{-2}$ & & $\%$ & & $\mathrm{mmol} \mathrm{m}^{-2}$ & & $\%$ & $\mathrm{gCO}_{2}$ eq m ${ }^{-2}$ & $\%$ \\
\hline $\begin{array}{l}\text { Eastmain } 1 \text { res., } \\
2007-2008\end{array}$ & 8747 & 2654 & 11401 & 23 & 7 & 1 & 7 & 7 & 509 & $98.6 \%$ \\
\hline $\begin{array}{l}\text { Eastmain } 1 \text { res., } \\
2008-2009\end{array}$ & 7374 & 3348 & 10723 & 31 & 20 & 1 & 21 & 5 & 493 & $95.6 \%$ \\
\hline $\begin{array}{l}\text { Mistumis Lake, } \\
\text { 2007-2008 }\end{array}$ & 3248 & 1392 & 4640 & 30 & 2 & 0 & 3 & 12 & 207 & $98.8 \%$ \\
\hline $\begin{array}{l}\text { Mistumis Lake, } \\
\text { 2008-2009 }\end{array}$ & 1528 & 1658 & 3186 & 52 & 8 & 1 & 10 & 13 & 150 & $93.5 \%$ \\
\hline $\begin{array}{l}\text { Clarkie Lake, } \\
\text { 2008-2009 }\end{array}$ & 903 & 834 & 1737 & 48 & 3 & 1 & 3 & 18 & 80 & $95.9 \%$ \\
\hline
\end{tabular}

was related to bacterial respiration. Moreover, the highest $p \mathrm{CO}_{2}$ values and winter $\mathrm{CO}_{2}$ increase rates were observed at Eastmain 1 reservoir. This was expected, since it is a young reservoir flooded only four years ago (in 2006), and the flooding of large quantities of organic matter is known to lead to an increase in dissolved $p \mathrm{CO}_{2}$ through an increase in bacterial activity (Tremblay et al., 2005; Tadonkélé et al., 2005). After an initial peak, generally reached within the first years few after flooding, $\mathrm{CO}_{2}$ flux and partial pressure decline, reaching values comparable to those of natural aquatic ecosystems within about 10 years (Tremblay et al., 2005). After this transition period, $\mathrm{CO}_{2}$ emissions are related to carbon entering the reservoir through runoff from the watershed or autochthonous primary production (Marty et al., 2005; Matthews et al., 2005). In the case of Eastmain 1 reservoir, the return to natural aquatic ecosystem values (i.e., values in the same range as nearby lakes) occurred the third year after flooding (2008) (Tremblay et al., 2009).

\section{4 $\mathrm{CH}_{4}$ emissions}

In accordance with the fact that most of the $\mathrm{CH}_{4}$ produced in the anoxic sediment may have been oxidized at the sedimentwater interface (Frenzel et al., 1990), and that $\mathrm{CH}_{4}$ escaping from the sediment-water interface would have been slowly oxidized in the water column (Wang et al., 1996), no clear $\mathrm{CH}_{4}$ accumulation was observed under the ice, especially in 2008. In 2007, at three of the seven stations where $p \mathrm{CH}_{4}$ was sampled, $p \mathrm{CH}_{4}$ increased with depth, probably due to the weak oxygen concentration there, as observed by Kortelainen et al. (2000). The ancillary available information (e.g., sampling station location, type of flooded land) cannot explain the origin of the high $p \mathrm{CH}_{4}$ observed at these stations. Huttunen et al. (2004) also observed no $\mathrm{CH}_{4}$ accumulation under ice cover in a small boreal lake during three consecutive late winters. Similar results were observed in four reservoirs in Manitoba over three years and in three reservoirs in 
Québec over 18 months (Demarty et al., 2009). Finally, a recent study by Juutinen et al. (2009) showed that partial pressure of $\mathrm{CH}_{4}$ in surface and hypolimnetic water is negatively correlated with oxygen and lake depth and area, whatever the season. This supports the observation of low winter partial pressure of $\mathrm{CH}_{4}$ in the large reservoir studied.

We found that diffusive $\mathrm{CH}_{4}$ emissions, in contrast to $\mathrm{CO}_{2}$ emissions, were of little concern in the boreal systems studied. Thix finding tallies with those of Juutinen et al. (2009) and Kortelainen et al. (2006) with respect to Finnish lakes. They reported that $\mathrm{CH}_{4}$ emissions amounted to $49 \mathrm{mmol} \mathrm{m}^{-2}$ (1.8\% of total emissions) (Juutinen et al., 2009), vs. $\mathrm{CO}_{2}$ emissions of only $3.5 \mathrm{~mol} \mathrm{~m}^{-2}$ (reported as $42 \mathrm{gC} \mathrm{m}^{-2}$ in Kortelainen et al., 2006).

Potential spring diffusive GHG emissions from lakes (given in Table 5) are comparable to those measured in a boreal lake by Huttunen et al. (2004; 103 to $128 \mathrm{gCO}_{2} \mathrm{eq} \mathrm{m}^{-2}$ ). Spring GHG emissions represented 23\% to $52 \%$ of annual GHG emissions. We also did annual estimates of diffusive GHG emissions at Robert Bourassa reservoir (Québec, Canada) with data collected in 2006 (up to 29 sampling stations) and we found higher potential spring emissions (22\% of annual emissions) than those reported by Duchemin et al. (2006) for shallow areas, whereas spring diffusive GHG flux amounted to only 7\% of annual flux at Robert Bourassa reservoir. Our results also demonstrated that, generally speaking, over $95 \%$ of annual diffusive GHG emissions from the studied systems are carbon dioxide.

\section{Summary}

We have provided the results of surveys of partial pressure and diffusive flux of GHG in both lakes and a reservoir in northwestern Québec, which allowed us to reliably estimate spring GHG flux based on a few assumptions. The method we used to estimate spring emissions can be generally applied.

Spring diffusive GHG emissions accounted for a higher proportion of annual GHG emissions than what has been previously proposed, with $\mathrm{CO}_{2}$ being largely responsible for total annual diffusive emissions.

Acknowledgements. We would like to thank Stéphane Lorrain, Robin Bourgeois, Pierre David Beaudry, Valérie Guay, Patrice Delisle and Jean Louis Fréchette, who were involved in the project. This study was funded by Hydro-Québec.

Edited by: T. Laurila

\section{References}

Åberg, J., Bergström, A. K., Algesten, G., Oderback, K. S., and Jansson, M.: A comparison of the carbon balances of a natural lake (L. Örträsket) and a hydroelectric reservoir (L. Skinnmuddselet) in northern Sweden, Water Res., 38, 531-538, 2004.

Abril, G., Guérin, F., Richard, S., Delmas, R., Galy-Lacaux, C., Gosse, P., Tremblay, A., Varfalvy, L., Aurelio Dos Santos, M., and Matvienko, B.: Carbon dioxide and methane emissions and the carbon budget of a 10-year-old tropical reservoir (PetitSaut, French Guiana), Global Biogeochem. Cy., 19, GB4007, doi:10.1029/2005GB002457, 2005.

Anderson, C. B.: Understanding carbonate equilibria by measuring alkalinity in experimental and natural systems, J. Geosci. Educ., 50, 389-403, 2002.

Blais, A. M. and Tremblay, A: Aménagement hydroélectrique de l'Eastmain-1 - Étude des flux de gaz à effet de serre des milieux aquatiques: Synthèse des résultats de 2003 à 2005, Report by Environnement Illimité Inc., Hydro-Québec, submitted, 45 pp. and apps, 2007.

Carignan, R.: Automated determination of carbon dioxide, oxygen, and nitrogen partial pressures in surface waters, Limnol Oceanogr., 43, 969-975, 1998.

Carpenter, S. R., Cole, J. J, Pace, M. L., Van De Bogert, M., Bade, D. L., Bastviken, D., Gille, C. M., Hodgson, J. R., Kitchell, J. F., and Kritzberg, E. S: Ecosystem subsidies: Terrestrial support of aquatic food webs from ${ }^{13} \mathrm{C}$ addition to contrasting lakes, Ecology, 86, 2737-2750, 2005.

Chartrand, N., Schetagne, R., and Verdon, R.: Enseignements tirés du suivi environnemental au complexe La Grande, in: Proceedings of the 18th International Congress on Large Dams, Durban, South Africa, Paris: International Commission on Large Dams, 165-190, 7-11 November 1994.

Cole, J. J. and Caraco, N. F.: Atmospheric exchange of carbon dioxide in a low-wind oligotrophic lake measured by the addition of $\mathrm{SF}_{6}$, Limnol. Oceanogr., 43, 647-656, 1998.

Cole, J. J., Caraco, N. F., Kling, G. W., and Kratz, T. K.: Carbon dioxide supersaturation in the surface waters of lakes, Science, 265, 1568-1570, 1994.

Cole, J. J., Prairie, Y. T., Caraco, N. F., McDowell, W. H., Tranvik, L. J., Striegl, R. G., Duarte, C. M., Kortelainen, P., Downing, J. A., Middelburg, J. J., and Melack, J.: Plumbing the global carbon cycle: Integrating inland waters into the terrestrial carbon budget, Ecosystems, 10, 172-185, 2007.

Del Giorgio, P. A, Cole, J. J., and Cimbleris, A.: Respiration rates in bacteria exceed phytoplankton production in unproductive aquatic systems, Nature, 385, 148-151. 1997.

Del Giorgio, P. A., Cole, J. J., Caraco, N. F., and Peters, R. H.: Linking planktonic biomass and metabolism to net gas fluxes in northern temperate lakes, Ecology, 80, 1422-1431, 1999.

Demarty, M., Bastien, J., and Tremblay, A.: Aménagement hydroélectrique de l'Eastmain-1 - Étude des flux de gaz à effet de serre - Résultats été 2008, Joint report by Environnement Illimité inc. and Hydro-Québec, 67 pp. and apps, 2008.

Demarty, M., Bastien, J., Tremblay, A., Hesslein, R. H., and Gill, R.: Greenhouse gas emissions from boreal reservoirs in Manitoba and Québec, Canada, measured with automated systems, Environ. Sci. Technol., 43, 8908-8915, doi:10.1021/es8035658, 2009.

Duarte, C. M. and Prairie, Y. T.: Prevalence of heterotrophy and at- 
mospheric $\mathrm{CO}_{2}$ emissions from aquatic ecosystems, Ecosystems, 8, 862-870, 2005.

Duchemin, E., Lucotte, M., Canuel, R., and Soumis, N.: First assessment of methane and carbon dioxide emissions from shallow and deep zones of boreal reservoirs upon ice break-up, Lakes and Reservoirs: Research and Management, 11, 9-19, 2006.

Eugster, W., Kling, T., Jonas, T., McFadden, J. P., Wüest, J. P., MacIntyre, S., and Chapin, F. S.: $\mathrm{CO}_{2}$ exchange between air and water in an Arctic Alaskan and midlatitude Swiss lake: Importance of convective mixing, J. Geophys. Res., 108(D12), 4362, doi:10.1029/2002JD002653, 2003.

Forster, P., Ramaswamy, V., Artaxo, P., Berntsen, T., Betts, R., Fahey, D. W., Haywood, J., Lean, J., Lowe, D. C., Myhre, G., Nganga, J., Prinn, R., Raga, G., Schulz, M., and Van Dorland, R.: Changes in atmospheric constituents and in radiative forcing, in: Climate Change 2007: The Physical Science Basis. Contribution of Working Group I to the Fourth Assessment Report of the Intergovernmental Panel on Climate Change, edited by: Solomon, S., Qin, D., Manning, M., Chen, Z., Marquis, M., Averyt, K. B., Tignor, M., and Miller, H. L., Cambridge University Press, Cambridge and New York, 2007.

Frenzel, P., Thebrath, B., and Conrad R.: Oxidation of methane in the oxic surface layer of a deep lake sediment (Lake Constance), FEMS Microbiol. Ecol., 73, 149-158, 1990.

Harrison, J. A., Maranger, R. J., Alexander, R. B., Giblin, A. E., Jacinthe, P. A., Mayorga, E., Seitzinger, S. P., Sobota, D. J., and Wollheim, W. M.: The regional and global significance of nitrogen removal in lakes and reservoirs, Biogeochemistry, 93, 143$157,2009$.

Houghton, J. T., Ding, Y., Griggs, D. J., Noguer, M., van der Linden, P. J., Dai, X., Maskell, K., and Johnson, C. A. (Eds.): Climate change 2001: The scientific basis. Contribution of Working Group I to the Third Assessment Report of the Intergovernmental Panel on Climate Change, Cambridge University Press, Cambridge and New York, 2001.

Huttunen, J. T., Alm, J., Liikanen, A., Juutinen, S., Larmola, T., Hammar, T., Silvola, J., and Martikainen, P. J.: Fluxes of methane, carbon dioxide and nitrous oxide in boreal lakes and potential anthropogenic effects on the aquatic greenhouse gas emissions, Chemosphere, 52, 609-621, 2003.

Huttunen, J. T., Hammar, T., Manninen, P., Servomaa, K., and Martikainen, P. J.: Potential springtime greenhouse gas emissions from a small southern boreal lake (Keihäsjärvi, Finland), Boreal Environ. Res., 9, 421-427, 2004.

Intergovernmental Panel on Climate Change (IPCC): Guidelines for National Greenhouse Gas Inventories, edited by: Eggelston, S., Buendia, L., Miwa, K., Ngara, T., and Tanabe, K., Institute for Global Environmental Strategies for the IPCC, 2006.

Juutinen, S., Rantakari, M., Kortelainen, P., Huttunen, J. T., Larmola, T., Alm, J., Silvola, J., and Martikainen, P. J.: Methane dynamics in different boreal lake types, Biogeosciences, 6, 209223, doi:10.5194/bg-6-209-2009, 2009.

Keller M. and Stallard, R. F: Methane emission by bubbling from Gatun Lake Panama, J. Geophys. Res., 99, 8307-8319, 1994.

Kling, G. W., Kipphut, G. W., and Miller, M. C.: The flux of $\mathrm{CO}_{2}$ and $\mathrm{CH}_{4}$ from lakes and rivers in arctic Alaska, Hydrobiologia, 240, 23-36, 1992.

Kortelainen, P., Huttunen, J. T., Väisänen, T., Mattson, T., Karjalainen, P., and Martikainen, P. J.: $\mathrm{CH}_{4}, \mathrm{CO}_{2}$ and $\mathrm{N}_{2} \mathrm{O}$ super- saturation in 12 Finnish lakes before and after ice-melt, Verh. Internat. Verein. Limnol., 27, 1410-1414, 2000.

Kortelainen, P., Rantakari, M., Huttunen, J. T., Mattson, T., Alm, J., Juutinen, S., Larmola, T., Silvola, J., and Martikainen, P. J.: Sediment respiration and lake trophic state are important predictors of large $\mathrm{CO}_{2}$ evasion from small boreal lakes, Glob. Change Biol., 12, 1554-1567, doi:10.1111/j.1365-2486.2006.01167, 2006.

Lide, D. R.: CRC Handbook of Chemistry and Physics, 88th edn., CRC, New York, 2007.

MacIntyre, S., Wanninkhof, R., and Chanton, J. P.: Trace gas exchange across the air-water interface in freshwater and costal marine environments, in: Biogenic trace gases: Measuring emissions from soil and water, edited by: Matson, P. A. and Harriss, R. C., Blackwell Science, Oxford, 52-97, 1995.

Marty, J., Planas, D., Pinel-Alloul, B., and Méthot, G.: Planktonic community dynamics over time in a large reservoir and their influence on carbon budgets, in: Greenhouse gas emissions: Fluxes and processes, hydroelectric reservoirs and natural environments, edited by: Tremblay, A., Varfalvy, L., Roehm, C., and Garneau, M., Springer, Berlin, Heidelberg, New York, 421-440, 2005.

Matthews, C. J. D., Joyce, E. M., St. Louis, V. L., Schiff, S. L., Venkiteswaran, J. J., Hall, B. D., Bodaly, R. A., and Beaty, K. G.: Carbon dioxide and methane production in small reservoirs flooding upland boreal forest, Ecosystems, 8, 267-285, 2005.

Michmerhuizen, C. M. and Striegl, R. G.: Potential methane emission from north-temperate lakes following ice melt, Limnol. Oceanogr., 4, 985-991, 1996.

Morel, F. M. M.: Energetics and kinetics: Principles of aquatic chemistry, Wiley, New York, 37-92, 1983.

NOAA: National Oceanic and Atmospheric Administration, www. noaa.gov, 2010.

Pace, M. L., Cole, J. J., Carpenter, S. R., Kitchell, J. F., Hodgson, J. R., Van De Bogert, M. C., Bade, D. L., Kritzberg, E. S., and Bastviken, D.: Whole-lake carbon-13 additions reveal terrestrial support of aquatic food webs, Nature, 427, 240-243, 2004.

Pace, M. L. and Prairie, Y. T.: Respiration in lakes, in: Respiration in aquatic ecosystems, edited by: Del Giorgio, P. A. and le B. Williams, P. J., Oxford University Press, 103-121, 2005.

Planas, D., Paquet, S., and Saint Pierre, A.: Productionconsumption of $\mathrm{CO}_{2}$ in reservoirs and lakes in relation to plankton metabolism, in: Greenhouse gas emissions: Fluxes and processes, hydroelectric reservoirs and natural environments, edited by: Tremblay, A., Varfalvy, L., Roehm, C., and Garneau, M., Springer, Berlin, Heidelberg, New York, 483-503, 2005.

Richey, J. E., Devol, A. H., Wofy, S. C., Victoria, R., and Riberio, M. N. G.: Biogenic gases and the oxidation and reduction of carbon in Amazon River and floodplain waters, Limnol. Oceanogr., 33, 551-561, 1988.

Riera, J. L., Schindler, J. E., and Kratz, T. K.: Seasonal dynamics of carbon dioxide and methane in two clear-water lakes and two bog lakes in northern Wisconsin, USA, Can. J. Fish. Aquat. Sci., 56, 265-274, 1999.

Rosa, L. P., Dos Santos, M. A., Matvienko, B., Dos Santos, E. O., and Sikar, E.: Greenhouse gas emissions from hydroelectric reservoirs in tropical regions, Climatic Change, 66, 9-21, 2004.

Roehm, C. and Tremblay, A.: Role of turbines in carbon dioxide emissions from two boreal reservoirs, Québec, Canada, J. Geophys. Res., 111, D24101, doi:10.1029/2006JD007292, 2006. 
Rudd, J. W. M., Harris, R., Kelly, C. A., and Hecky, R. E: Are hydroelectric reservoirs significant sources of greenhouse gases?, Ambio, 22, 246-248, 1993.

Schetagne, R.: Water quality modifications after impoundment of some large northern reservoirs, Arch. Hydrobiol. Beih., 40, $223-$ 229, 1994.

St. Louis, V. L., Kelly, C. A., Duchemin, E., Rudd, J. W. M., and Rosenberg, D. M.: Reservoir surfaces as sources of greenhouse gases to the atmosphere: A global estimate, Bioscience, 50, 766$775,2000$.

Soumis, N., Duchemin, E., Canuel, R., and Lucotte, M.: Greenhouse gas emissions from reservoirs of the western United States, Global Biogeochem. Cy., 18, GB3022, doi:10.1029/2003GB002197, 2004.

Striegl, R. G., Kortelainen, P., Chanton, J. P., Wickland, K. P., Bugna, G. C., and Rantakari, M.: Carbon dioxide partial pressure and ${ }^{13} \mathrm{C}$ content of north temperate and boreal lakes at spring ice melt, Limnol. Oceanogr., 46, 941-945, 2001.

Tadonkélé, R. D., Planas, D., and Paquet, S.: Bacterial activity in the water column and its impact on the $\mathrm{CO}_{2}$ efflux, in: Greenhouse gas emissions: Fluxes and processes, hydroelectric reservoirs and natural environments, edited by: Tremblay, A., Varfalvy, L., Roehm, C., and Garneau, M., Springer, Berlin, Heidelberg, New York, 467-482, 2005.

Tranvik, L. J.: Allochthonous dissolved organic-matter as an energy-source for pelagic bacteria and the concept of the microbial loop, Hydrobiologia, 229, 107-114, 1992.
Tremblay, A. and Bastien, J.: Greenhouse gases flux from a new reservoir and natural water bodies in Québec, Canada, Verh. Intern. Verein. Limnol., 30, 866-869, 2009.

Tremblay, A., Therrien, J., Hamlin, B., Wichmann, E., and Ledrew, L. J.: GHG emissions from boreal reservoirs and natural aquatic ecosystems, in: Greenhouse gas emissions: Fluxes and processes, hydroelectric reservoirs and natural environments, edited by: Tremblay, A., Varfalvy, L., Roehm, C., and Garneau, M., Springer, Berlin, Heidelberg, New York, 209-231, 2005.

Tremblay, A., Demers, C., and Bastien, J.: GHG fluxes $\left(\mathrm{CO}_{2}, \mathrm{CH}_{4}\right)$ of the first three years after flooding of the Eastmain-1 reservoir (Quebec, Canada), Annual Conference on Hydraulic Engineering, Waterpower and Climate Change, Necessary Strategies New Technologies, Dresden, Germany, 2009.

Tremblay, A., Bastien, J., Bonneville, M. C., Del Giorgio, P., Demarty, M., Garneau, M., Hélie, J. F., Pelletier, L., Prairie, Y. T., Roulet, N., Strachan, I., and Teodoru, C.: Net greenhouse emissions at Eastmain 1 reservoir, Quebec, Canada, in: Proceedings of the 21st World Energy Congress, Montréal, 12-16 September 2010.

Wanninkhof, R.: Relationship between wind speed and gas exchange over the ocean, J. Geophys. Res., 97, 7373-7382, 1992.

Wang, Z., Zeng, D., and Patrick Jr., W. H.: Methane emissions from natural wetlands, Environ. Monit. Assess., 42, 143-161, 1996.

Weiss, R. F.: Carbon dioxide in water and seawater: The solubility of a non-ideal gas, Mar. Chem., 2, 203-215, 1974. 